\title{
Serological Study of Cellulomonas
}

\author{
A. R. BRADEN ${ }^{1}$ AND D. W. THAYER \\ Department of Biological Sciences, Texas Tech University, Lubbock, Texas 79409
}

\begin{abstract}
Cell wall antigens from each of six Cellulomonas species and two soil isolates were prepared. Cross-reactions were set up with antisera obtained through inoculation of New Zealand white rabbits. The percentage of cross-reaction ranged from 12 to 93 . The known cellulomonads clustered in a range of 68 to $93 \%$ with one exception: $C$. uda with $C$. subalbus at $43 \%$. The soil isolates demonstrated a much lower affinity and thus were not considered cellulomonads. The cellulomonads, although similar to each other, demonstrated enough diversification to question their reduction to a single species.
\end{abstract}

The genus Cellulomonas has maintained a fluid status ever since Bergey et al. (1) proposed this genus for strains isolated by Kellerman, McBeth, and co-workers $(10,11,13,14)$. To date these organisms have been assigned to three different orders $(1-3,18)$ and have been recently defined as a single species, Cellulomonas flavigena (3).

Cell wall composition of the genus Cellulomonas was reported to be uniform (9). However, Cummins (5) cautioned against interpreting qualitative cell wall analyses directly in terms of taxonomic relationships unless they are reinforced by serological and other tests. In view of the similarity of the pattern of cell wall components, it seemed possible that an immunological study of the cell wall from each of six species of Cellulomonas and two soil isolates would be useful for studying cross-reactions. Cummins and Harris (4) used cell walls as antigens in agglutination tests, enabling them to identify common antigens in cell walls.

\section{MATERIALS AND METHODS}

Cellulomonas species in this investigation were obtained from the American Type Culture Collection. The study included $C$. biazotea ATCC 486, $C$. fimi ATCC 484, C. flavigena ATCC 482, C. gelida ATCC 488, C. subalbus ATCC 489, and C. uda ATCC 491. Also included were two soil isolates, JM98A and JM99A, biochemically identified as cellulomonads (19).

Cell wall antigens were prepared from cells serially grown at least three times in TYPG broth, which consisted of the following: tryptone (Difco), 5 g; yeast extract (BBL), $5 \mathrm{~g} ; \mathrm{K}_{2} \mathrm{HPO}_{4}, 5 \mathrm{~g}$; glucose, 0.5 $\mathrm{g}$; and distilled water to $1,000 \mathrm{ml}$. The $\mathrm{pH}$ was adjusted to 7.2. One milliliter of inoculum was transferred to each of five triple-baffled, 2,800-ml Fernbach flasks containing $500 \mathrm{ml}$ of broth and incubated for $24 \mathrm{~h}$ at $37 \mathrm{C}$ with agitation at $300 \mathrm{rpm}$. The cells were harvested by centrifugation at $3,020 \times g$, at $4 \mathrm{C}$

${ }^{1}$ Present address: Baylor College of Dentistry, Department of Microbiology, Dallas, Tex. 75226. for $25 \mathrm{~min}$, washed twice with distilled water, and suspended in distilled water. Disruption of the cells with a French pressure cell (7) was performed at $4 \mathrm{C}$. Subsequent cell wall treatment was by the method of Robinson (17). Cell walls and unsoluble cell debris were harvested by centrifugation at $17,300 \times \mathrm{g}$ for 20 min at $4 \mathrm{C}$. The crude cell wall deposit, resuspended in distilled water, was centrifuged at $480 \times g$ for 10 min at $4 \mathrm{C}$ to remove whole cells and then at 12,100 $\times g$ for $15 \mathrm{~min}$ to harvest cell walls. The cell wall fractions were sequentially digested with $0.5 \%$ (wt/ vol) $\mathrm{KOH}$ in EtOH; 0.05 M phosphate buffer (pH 7.6) containing $0.5 \mathrm{mg}$ each of ribonuclease and trypsin per $\mathrm{ml}$; and $0.02 \mathrm{M} \mathrm{NHCl}$ containing $1 \mathrm{mg}$ of crystalline pepsin per $\mathrm{ml}$. The resulting purified cell wall mucopeptide was washed three times with physiological saline and suspended in $10 \mathrm{ml}$ of saline. All suspensions were stored at $2 \mathrm{C}$ until ready for use.

Protein content of antigen preparations was determined by the method of Folin-Ciocalteau (12) at a wavelength of $740 \mathrm{~nm}$. Standard solutions of crystalline bovine serum albumin (fraction V) were prepared in physiological saline.

Thimerosal was added to the antigen suspension to yield a dilution of 1:10,000. Five New Zealand white rabbits received an antigen preparation 1:1 (antigen:Freund incomplete adjuvant, Difco), and one received an equal amount of saline and Freund incomplete adjuvant. Injections were made subcutaneously on alternate sides for 7 weeks. The total amount of protein injected was as follows: $C$. biazotea, $100 \mu \mathrm{g} ;$ C. fimi, $50 \mu \mathrm{g} ; C$. flavigena, $100 \mu \mathrm{g} ; C$. gelida, $100 \mu \mathrm{g} ;$ C. uda, $75 \mu \mathrm{g}$.

Final bleeding was accomplished by cardiac puncture. Collected sera were filter-sterilized and preserved with Thimerosal at a final dilution of 1:10,000 (8). Antibody titers were determined by the quantitative precipitin and optimal proportions method (8) at the end of 4 and 7 weeks. Using the optimal proportions method, agglutinin titers at the end of 7 weeks were as follows: $C$. biazotea, 1:200; C. fimi, 1.50; C. flavigena, 1:100; C. gelida, 1:100; C. uda, $1: 200$.

Quantitative agglutination tests were performed in triplicate by the method of Kabat and Mayer (8). The homologous and heterologous protein precipitates were quantitated by the Folin-Ciocalteau 
method. The volume of antisera, $0.4 \mathrm{ml}$, remained constant in all tests.

The percent relatedness was calculated using the following formula: amount of heterologous protein precipitated divided by the amount of homologous protein precipitated $\times 100$. The protein values were corrected for the amount of antigen added and for the amount of precipitate formed in the saline control for the homologous system. Optimum precipitation in the homologous system was obtained by adding $0.06 \mathrm{ml}$ of antigen solution. Therefore, this amount was added in all heterologous tests.

\section{RESULTS}

The percent cross-reaction varying with species ranged from 43 to 93 . The soil isolates, initially classified as Cellulomonas species, demonstrated a much lower affinity than the type strains, with a maximum cross-reaction of $56 \%$ and a low of $12 \%$ (Fig. 1 and 2).

\section{DISCUSSION}

The quantitative agglutination procedure indicated that the cellulomonads had common cell wall antigens. However, in no instance did a heterologous reaction equal the homologous. Thus, the reduction of these organisms to a single species was questionable. The weaker reactions of $C$. gelida and $C$. uda with the antisera from the other cellulomonads suggested that the two have fewer common cell wall antigens. This was supported to some extent by Keddie et al. (9). Their work differentiated $C$. $u d a$ by the presence of glycine as a major cell wall component. The two strongest relationships were exhibited by $C$. biazotea with $C$. flavigena and $C$. gelida with $C$. uda. However, in a 70-character, single-linkage computer analysis, Davis and Newton (6) presented a dendrogram where $C$. flavigena and $C$. biazotea achieved a $77 \%$ similarity. Since these were the only two cellulomonads tested, it was not possible to make a comparison with the other species. In other computer analyses of coryneform bacteria, Masuo and Nakagawa $(15,16)$ showed five species of Cellulomonas to

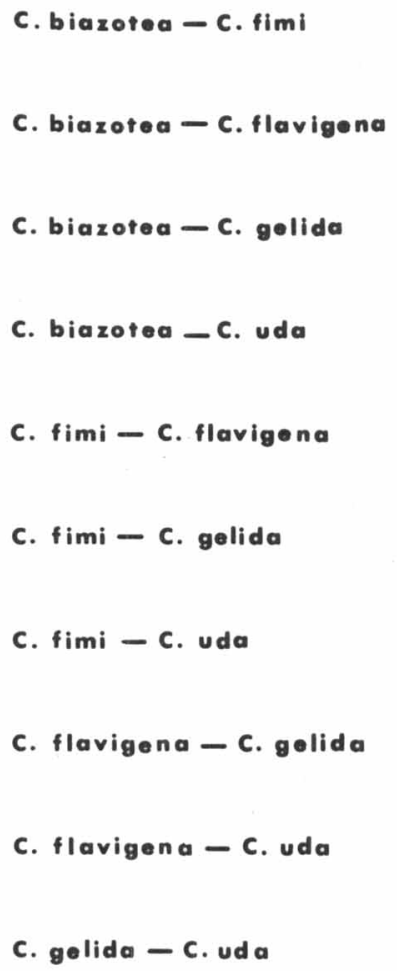

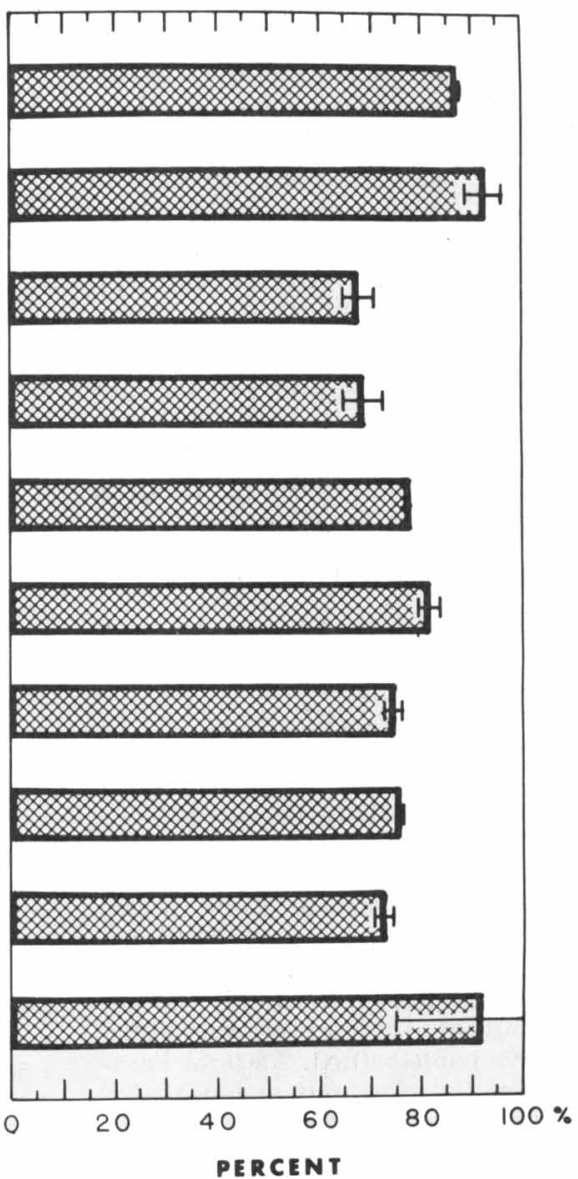

Fig. 1. Serological relation of Cellulomonas species. The results are the averages of reciprocal crossreactions. Six different determinations were made. 


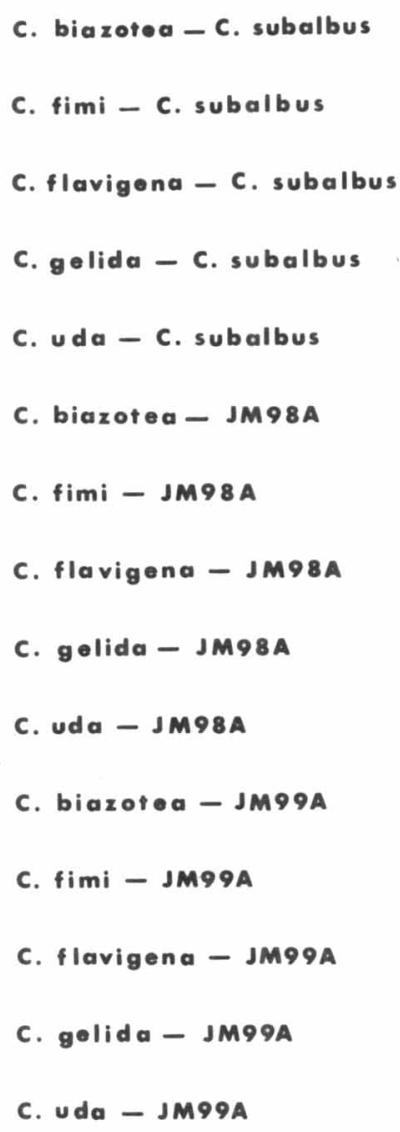

Fig. 2. Serological relation of Cellulomonas species to C. subalbus and unknown soil isolates. The results are the averages of three determinations.

be 80 to $90 \%$ similar based on 84 characters in one instance and 106 in the other. The serological data presented here indicated a much greater differentiation. The range of crossreaction varied from a low with $C$. $u d a$ and $C$. subalbus of $43 \%$ to a high of $93 \%$ for C. flavigena with $C$. biazotea and C. $u d a$ with $C$. gelida.

Although the cellulolytic soil isolates resembled the cellulomonads morphologically and biochemically, they demonstrated a much lower affinity for the cell wall antigens. The results indicated that JM98A had fewer common cell wall antigens than JM99A, but neither approached the magnitude of the crossreactions of the known Cellulomonas species with one exception. C. $u d a$ seemed to share more cell wall antigens with the soil isolate JM99A than with C. subalbus. Thus, it seemed from this study that, although the Cellulomonas species shared many of their cell wall antigens, the strains were not identical. Reduction of these organisms to a single species should be the subject of further investigation.

\section{ACKNOWLEDGMENTS}

This investigation was supported in part by funds provided by the International Center for Arid and Semi-Arid Land Studies, Texas Tech University, and the National Science Foundation NSF GR \#GU-3759.

\section{REPRINT REQUESTS}

Address reprint requests to: Dr. D. W. Thayer, Department of Biological Sciences, Texas Tech University, P. O. Box 4149, Lubbock, Tex. 79409. 


\section{LITERATURE CITED}

1. Bergey, D. H., F. C. Harrison, R. S. Breed, B. N. Hammer, and F. M. Huntoon (ed.). 1923. Bergey's manual of determinative bacteriology, 1st ed. The Williams and Wilkins Co., Baltimore.

1a. Brock, T. D. 1970. Biology of microorganisms. Prentice-Hall, Inc., Englewood Cliffs, New Jersey.

2. Breed, R., E. G. D. Murray, and N. R. Smith (ed.). 1957. Bergey's manual of determinative bacteriology, 7th ed. The Williams and Wilkins Co., Baltimore.

3. Buchanan, R. E., and N. E. Gibbons (ed.). 1974. Bergey's manual of determinative bacteriology, 8th ed. The Williams and Wilkins Co., Baltimore.

4. Cummins, C. S., and H. Harris. 1956. The chemical composition of the cell wall in some gram-positive bacteria and its possible value as a taxonomic character. J. Gen. Microbiol. 14:583-600.

5. Cummins, C. S. 1962. Chemical composition and antigenic structure of cell walls of Corynebacterium, Mycobacterium, Nocardia, Actinomyces and Arthrobacter. J. Gen. Microbiol. 28:35-50.

6. Davis, G. H. G., and K. G. Newton. 1969. Numerical taxonomy of some named coryneform bacteria. J. Gen. Microbiol. 56:195-215.

7. French, C. S., and H. W. Milner. 1955. Disintegration of bacteria and small particles by high-pressure extrusion, p. 64-67. In S. P. Colowick and N. O. Kaplan (ed.), Methods in enzymology, vol. 1. Academic Press Inc., New York.

8. Kabat, E. A., and M. M. Mayer. 1961. Experimental immunochemistry, 2nd ed. Charles C. Thomas, Springfield, Illinois.

9. Keddie, R. M., G. G. S. Leask, and J. M. Frainger. 1966. A comparison of coryneform bacteria from soil and herbage: cell wall composition and nutrition. J. Appl. Bacteriol. 29:17-43.
10. Kellerman, K. T., and I. G. McBeth. 1912. The fermentation of cellulose. Zentralbl. Bakteriol. Parasitenkd. Infektionskr. Hyg. Abt. 2 34:484-489.

11. Kellerman, K. T., I. G. McBeth, and N. R. Smith. 1913. Identification and classification of cellulose dissolving bacteria. Zentralbl. Bakteriol. Parasitenkd. Infektionskr. Hyg. Abt. 2 39:502-522.

12. Layne, E. 1957. Spectrophotometric and turbidometric methods for measuring proteins. II. Protein estimation with the Folin-Ciocalteau reagent, p. 448-450. In S. F. Colowick and W. O. Kaplan (ed.), Methods in enzymology, vol. 3. Academic Press Inc., New York.

13. McBeth, I. G., and F. M. Scales. 1913. The destruction of cellulose by bacteria and filamentous fungi. U.S.D.A. Bureau of Plant Industry Bull. 266.

14. McBeth, I. G. 1916. Studies on the decomposition of cellulose in soils. Soil Sci. 1:437-487.

15. Masuo, E., and T. Nakagawa. 1969. Numerical classification of bacteria. Part I. Computer analysis of coryneform bacteria. Agric. Chem. Soc. Jpn. J. 42(7/ 12):627-632

16. Masuo, E., and T. Nakagawa. 1969. Numerical taxonomy of bacteria. II. Analysis of "coryneform bacteria" and related ones on the basis of overall similarity of phenotypic characters. Annu. Rep. Shionogi Res. Lab. 19:121-123.

17. Robinson, D. 1968. The use of cell wall analysis and gel electrophoresis for the identification of coryneform bacteria, p. 85-92. In B. M. Gibbs and D. A. Shapton (ed.), Identification methods for microbiologists, part B. Academic Press Inc., New York.

18. Stanier, R. Y. 1941. Studies on marine agar digesting bacteria. J. Bacteriol. 42:527-557.

19. Thayer, D. W., S. P. Yang, A. B. Key, H. H. Yang, and J. W. Barker. 1975. Production of cattle feed by the growth of bacteria on mesquite wood. Dev. Ind. Microbiol. 16:465-474. 